\title{
Comparative Evaluation of Viability and Function of Albino Rabbit Periodontal Ligament Fibroblasts in Various Media (In Vitro Study)
}

\author{
Original \\ Rabab Hassan ${ }^{1}$ and Nihal Kabel ${ }^{2}$ \\ Article \\ 'Department of Oral Biology, Faculty of Dentistry, Ain Shams University, Cairo, Egypt. \\ ${ }^{2}$ Department of Pediatric Dentistry and Community Dentistry, Faculty of Dentistry, Misr \\ University for Science and Technology, Cairo, Egypt.
}

\begin{abstract}
Background: Tooth avulsion is one of traumatic injuries that cause damage to periodontal ligament (PDL) tissues. Avulsed tooth should be stored in a suitable storage medium to preserve the vitality of the PDL fibroblasts (PDLFs).

Aim: To assess and compare the effect of various media on albino rabbit's PDLFs viability and basic fibroblast growth factor (b-FGF) protein and gene expressions at different time intervals.

Material and Methods: Periodontal ligament stem cells (PDLSCs) were isolated from molars of albino rabbit then differentiated into PDLFs. The PDLFs were cultured in different media (contact lens solution, skimmed milk, Dentosafe and alcohol free mouthwash) for $1 \mathrm{~h}, 12 \mathrm{~h}$ and $24 \mathrm{~h}$. Phosphate buffered saline (PBS) was used as control medium. Cell viability was assessed by MTT assay. b-FGF protein and gene expression levels were detected by immunofluorescence (IF) staining and Quantitative Real Time-Polymerase Chain Reaction (qRT-PCR) respectively. Data from MTT assay and H-score of IF staining were statistically analyzed using ANOVA test and multiple two groups comparisons pos hoc test.

Results: Examination of isolated PDLSCs at different passages showed various shapes of cells from rounded to spindle shaped. The differentiated PDLFs showed positive IF reaction. Statistical analysis of tested media at different time intervals represented that; PBS had the highest mean of fibroblastic cell viability $\%$ and $\mathrm{H}$-score, followed by Dentosafe, skimmed milk, contact lens solution and mouthwash respectively. Gene expression of b-FGF was up-regulated in Dentosafe and skimmed milk while it was down-regulated in mouthwash.

Conclusions: Dentosafe is more effective in maintenance of PDLFs viability and function than the other tested media. Mouthwash is not recommended as a storage media for PDLFs.
\end{abstract}

Received: 06 October 2020, Accepted: 24 October 2020

Key Words: Avulsed tooth; b-FGF; immunofluorescence; MTT assay; storage media.

Corresponding Author: Rabab Hassan, PhD, Department of Oral Biology, Faculty of Dentistry, Ain-Shams University, Cairo, Egypt, Tel.: +20 1224101540, E-mail: rabab.hassan@dent.asu.edu.eg

ISSN: $1110-0559$, Vol. 44, No.3

\section{INTRODUCTION}

Tooth avulsion is one of traumatic injuries that result in total dislocation of a tooth from its alveolar socket causing damage of periodontal ligament (PDL) tissues and necrosis of dental pulp due to breakdown of neurovascular supplies ${ }^{[1,2]}$. Immediate replantation and storing of avulsed tooth in an appropriate transport medium are essential factors to maintain the vitality of PDL fibroblasts (PDLFs) and the expression of basic fibroblast growth factor (b-FGF) responsible for PDL tissues regeneration, and to diminish post-replantation complications such as ankylosis or external root resorption ${ }^{[3-9]}$.

Contact lens solution is mainly a saline solution with additives such as fatty acid monoester, a cationic antimicrobial element and preservatives that may maintain the viability of PDL cells ${ }^{[10]}$.

Milk is a widely used storage medium because of its low bacterial content and nutritional substances which contribute in isolation of bone tissue from the tooth and thus reduce the probability of ankylosis ${ }^{[1]]}$.
Dentosafe is the marketable name of a tooth rescue box containing special cell culture medium, amino acids, vitamins and glucose that help in maintaining vitality of PDL cells ${ }^{[12]}$.

Mouthwash is one of the disinfected solutions which exists at home and is used in improving oral hygiene by preventing plaque, caries and gingivitis ${ }^{[13]}$.

This research was designed to evaluate and compare the viability as well as b-FGF protein and gene expressions of rabbit PDLFs with various media (contact lens solution, skimmed milk, Dentosafe and mouthwash) at different storage times.

\section{MATERIALS AND METHODS}

\section{Ethical statement}

This study was approved by the Ethics Committee, Ain Shams University (approval number: FDASU-REC IR072004). 


\section{I-Tested media}

- Contact lens solution ( $\mathrm{ReNu}{ }^{\circledR}$ MultiPlus Solution Multifunctions, USA).

- $\quad$ Pasteurized fresh skimmed milk (Dina Farm ${ }^{\circledR}$, Egypt).

- Dentosafe (MEDICE Arzneimittel Pütter GmbH \& Co KG, Germany)

- Alcohol free mouthwash (Listerine ${ }^{\circledR}$ Total Care Zero Alcohol, Italy). The mouthwash was used with concentration $1 \%{ }^{[14]}$.

\section{II- Sample collection}

To obtain PDL tissues, one clinically healthy male albino rabbit weighing $600 \mathrm{gm}$ was used in this study. The rabbit was anesthetized by using general anesthesia $10 \mathrm{mg} / \mathrm{kg}$ ketamine hydrochloride (Gutian Pharmaceutical, Fujian, China), then gingiva was separated, six maxillary and six mandibular molars were luxated with an elevator and extracted with hand instrument. The extracted molars were immersed immediately in transfer solution phosphate buffered saline $(\mathrm{PBS})+10 \%$ penicillin/streptomycin ${ }^{[15]}$. After molars extraction, the rabbit was sacrificed by over dose of ketamin. This procedure was performed at Animal House of "The Medical Research Center" Faculty of Medicine, Ain Shams University.

\section{III- Cell culture}

All steps of cell culture were performed in Central Lab of Stem Cells and Biomaterials Applied Research (CLSCBAR), Faculty of Dentistry, Ain Shams University and in Global Labs, Cairo, Egypt. All cell culture procedures were completed under laminar flow tissue cultureHood with proper aseptic techniques.

\section{Primary culture of PDL stem cells (PDLSCs)}

Within the first hour after extraction and in laminar flow cabinet (Thermo MSC 1.2), each extracted molar was held with tweezer from the crown. The root surfaces were carefully washed using PBS then scraped using sterile surgical lancet to ensure removal of all the periodontal tissues attached to them. The excised PDL tissues were placed in a small plate and minced into small pieces then collected in sterile Eppendorf tubes and washed with PBS. After that, the PBS was replaced and tissues were digested using collagenase type I $1 \mathrm{mg} / \mathrm{ml}$ (Sigma-Aldrich, Germany) at $37^{\circ} \mathrm{C}$ in a water bath. Tissues were then homogenized by centrifugation. Supernatant was discarded and cell suspension was subsequently washed 3 times with PBS and centrifuged again to obtain a pellet of isolated cells.

Isolated PDLSCs were primary cultured in $20 \mathrm{ml}$ of Minimum Essential Medium (MEM) (Gibco, Thermosientific, Germany) containing 10\% fetal bovine serum (FBS) (Gibco, Thermosientific, Germany) and 1\% of penicillin G sodium (10.000UI), streptomycin $(10 \mathrm{mg})$ and amphotericin B $(25 \mu \mathrm{g})$ (Gibco, Thermosientific,
Germany). The cells were seeded in polystyrene tissue culture flask $\left(75 \mathrm{~cm}^{2}\right)$. The culture flask was incubated in a humidified $\mathrm{CO}_{2}$ incubator (Thermo Heracell 150i) at $37 \circ \mathrm{C}$ in $5 \% \mathrm{CO}_{2}$ and $95 \%$ air by volume. The medium was replaced every 2 days. The cultured cells were examined using phase contrast inverted microscope (LEICA Dmi80 inverted microscope platform + LASX software) to follow up the growth of the cells and to detect the appearance of any bacterial or fungal infection among the cultured cells. After the cells reached $80 \%$ confluence, the cells were harvested and the third passage was used ${ }^{[16,17]}$.

\section{Differentiation of PDLSCs to PDLFS}

For fibroblast differentiation, PDLSCs were cultured in microvascular endothelial cell medium (Gibco, Thermofisher, Germany) enriched with $2 \%$ fetal bovine serum, $50 \mu \mathrm{g} / \mathrm{mL}$ ascorbic acid, and Transforming Growth Factor beta (TGF- $\beta$ ) with concentration of $15 \mathrm{ng} / \mathrm{mL}$ and seeded in 6 -well plates $\left(5 \times 10^{4}\right.$ cells/well $)$. The medium was changed twice a week for one week until $70-75 \%$ confluence was achieved ${ }^{[18]}$.

\section{Recognition of differentiated PDLFs}

For examination of b-FGF expression, the differentiated cells were fixed on positively charged microscope slides in $4 \%$ warm formaldehyde. Then, slides were immunoflourecent (IF) stained using specific primary polyclonal antibody (Rabbit Anti-b-FGF (TSC22D1), cat no:PA5-38690) (Invitrogen; ThermoFisher Scientific, Hilden; Germany), and incubated overnight at $4{ }^{\circ} \mathrm{C}$. The slide was washed with PBS and incubated with Goat AntiRabbit IgG H\&L secondary antibody-Alexa Flour 488 (Invitrogen; ThermoFisher Scientific, Hilden; Germany). The slide was covered by Prolong Gold Antifade Reagent with DAPI "4', 6-diamidino-2-phenylindole" (Abcam, Cambridge, UK) and mounted overnight at room temperature. The specimens were examined and stored at $4^{\circ} \mathrm{C}$ away from light for long term storage ${ }^{[19]}$. The microscopic examination was performed by LABOMED Fluorescence microscope LX400, cat no: 9126000; USA. The cells were photographed at $100 \mathrm{x}$ and $400 \mathrm{x}$ magnifications.

\section{Assessment of cell viability}

The PDLFs were seeded in forty five 96-well culture plates $\left(1 \times 10^{4}\right.$ cells/well $)$ containing MEM and incubated in (Binder incubator, Binder $\mathrm{GmbH}$, Germany) at $37^{\circ} \mathrm{C}$ with $5 \% \mathrm{CO}_{2}$ for $24 \mathrm{~h}$ to allow cell attachment. At confluence, the MEM was removed and replaced by $100 \mu \mathrm{L}$ of four tested media including, \{contact lens solution ( $\mathrm{pH}$ 6.9), skimmed milk ( $\mathrm{pH}$ 6.7), Dentosafe ( $\mathrm{pH} 7.3$ ) and mouthwash (pH 7.1)\}. PBS (pH 7.4) was used as control medium. Plates were incubated at $37^{\circ} \mathrm{C}$ and $5 \% \mathrm{CO}_{2}$ and assessed for cell viability at three time intervals $(1 \mathrm{~h}$, $12 \mathrm{~h}$ and 24h). MTT (3-(4,5-dimethylthiazol-2-yl)-2,5diphenyltetrazolium bromide) tetrazolium reduction assay was used in this study to detect cell viability. After the end of each incubation period, the MTT solution $(1 \mathrm{mg} / \mathrm{mL})$ 
(Invitrogen, ThermoScientific, Germany) was added to each well and the plates were incubated at $37^{\circ} \mathrm{C}$ for $24 \mathrm{~h}$, then media and MTT solution were removed and $100 \mu \mathrm{L}$ of dimethyl sulfoxide (DMSO) (LC-MS Grade, Thermo Scientific) was added to each well to dissolve the formazan crystals. Cell viability was determined by measuring the optical density at $570 \mathrm{~nm}$ using a spectrophotometer (ELx800; Bio-Tek Instruments Inc., Winooski, VT, USA). The percentage of relative cell viability was calculated using the following formula: (tested media optical density/ control optical density) $\times 100^{[16]}$.

Assessment of b-FGF protein expression after incubation of PDLFs using immunofluorescence staining

After incubation of PDLFs in various media at different time intervals, the cells were IF stained using polyclonal rabbit Anti-b-FGF and examined for the protein expression of b-FGF. The cells were photographed from five fields randomly at $400 \mathrm{x}$ magnification. The IF staining intensity was scored according to the Four-Tier system: 0, no staining; 1, weak; 2, moderate; and 3, strong. The average percentage of PDLFs IF positive cells in each field at each intensity was calculated.

The H-score of each sample was calculated as follows: $\mathrm{H}$-score $=(\%$ of PDLFs stained at intensity $1 \mathrm{x} 1+\%$ of PDLFs stained at intensity $2 \times 2+\%$ of PDLFs stained at intensity $3 \times 3$ ). The $\mathrm{H}$-score ranged from $0-300$. H-score was performed using Camera software OptikaISview, version:3.9.0.605 (Optika microscopes Diagnostics, Italy).

Assessment of b-FGF gene expression using Quantitative Real Time-Polymerase Chain Reaction (qRT-PCR)

After incubation of PDLFs in each media at different incubation periods, total RNA was isolated using RNeasy extraction kit (Qiagen, Hilden, Germany), the extraction was conducted according to the manufacturer's protocol. Gene specific QuantiTect primer assay for b-FGF and $\beta$ actin (ACTB) was purchased from (Qiagen, Germany). All amplifications were conducted in a final reaction mixture $(20 \mu \mathrm{L})$ containing $500 \mathrm{nM}$ gene-specific primers, $2 \mathrm{xSYBR}$, and $6 \mu \mathrm{L}$ of template under the following conditions: denaturation at $95^{\circ} \mathrm{C}$ for $5 \mathrm{~min}, 40$ cycles at $95^{\circ} \mathrm{C}$ for $10 \mathrm{~s}$, $58^{\circ} \mathrm{C}$ for $15 \mathrm{~s}$, and $72^{\circ} \mathrm{C}$ for $15 \mathrm{~s}$ and a final extension at $72^{\circ} \mathrm{C}$ for $5 \mathrm{~min}$. Reactions were performed using a 5-plex Rotor-Gene (Qiagen, Germany). Fluorescence data were converted into cycle threshold (CT) measurements. Relative gene expression (Fold change) was calculated using $2^{-\Delta \Delta \mathrm{Ct}}$ formula. The gene expression is up-regulated when the fold change became $>1$ and down-regulated when the fold change became $<1^{[20]}$.

\section{IV-Statistical analysis}

All data from MTT assay and H-score were analyzed statistically. Numerical data were explored for normality by checking the distribution of data and using tests of normality (Kolmogorov-Smirnov and Shapiro-Wilk tests). Data were presented as mean values \pm standard deviation $( \pm \mathrm{SD})$. Comparison of numerical variables between the studied media was done using one way analysis of variance (ANOVA) test with post hoc multiple two groups comparisons. The probability value $(P$-value $)<0.001$ indicates high significance of the results while, $P$-value $\leq 0.05$ indicates significant results. Statistical analysis was performed with IBM SPSS Statistics for Windows, Version 23.0. Armonk, NY: IBM Corp.

\section{RESULTS}

\section{Primary culture of PDLSCs}

The cultured PDLSCs were distinguished from other cells by their tendency to adhere to tissue culture plastic flask floor. The examination of cultured PDLSCs with inverted microscope showed that, at day zero of culture, the cells appeared numerous and small rounded in shape (Figure 1a), at passage 1, fibroblast-like cells with vesicular nucleus were detected (Figure 1b). At the passage 2, clusters of cells with fibroblast-like morphology were seen, some cells appeared spindle in shape while others appeared stellate in shape with extended processes (Figure 1c). At passage 3, the cultured cells appeared numerous and spindle in shape (Figure 1d).

\section{Recognition of differentiated PDLFs by immunofluorescence stain}

Before fibroblastic differentiation, few numbers of PDLFs showed positive anti-b-FGF IF reactions and cells appeared rounded in shape (Figures 2a,b). After differentiation, PDLFs showed positive cell membrane and cytoplasmic IF reactions with detectable increase in number, the cells appeared spindle in shape with long cytoplasmic processes (Figures 2c,d).

\section{Cell viability}

Statistical analysis of MTT assay to measure fibroblast cells viability $\%$ of different media at the same incubation period represented that, at $1 \mathrm{~h}$ incubation, PBS had the highest mean of fibroblast cells viability $\%$, followed by Dentosafe which showed non-significant difference with PBS, followed by skimmed milk which illustrated nonsignificant difference with Dentosafe, then contact lens solution which demonstrated non-significant difference with skimmed milk. Mouthwash had the least mean of fibroblast cells viability $\%$ and there was non-significant difference with contact lens solution.

At $12 \mathrm{~h}$ and $24 \mathrm{~h}$ incubation, PBS had the highest mean of fibroblast cells viability $\%$, followed by Dentosafe which showed non-significant difference with PBS, then skimmed milk, and subsequently contact lens solution which showed non-significant difference with skimmed milk. Mouthwash revealed the least mean of fibroblast cells viability $\%$ (Table 1, Figure 3a). 
Statistical analysis of MTT assay to measure fibroblast cells viability $\%$ at different durations of the same medium represented that, PBS had non-significant difference at all durations. Contact lens solution and mouthwash showed the highest mean of fibroblast cells viability $\%$ at $12 \mathrm{~h}$, followed by $1 \mathrm{~h}$, then $24 \mathrm{~h}$ and there was non-significant difference with $1 \mathrm{~h}$. Skimmed milk had the highest mean of fibroblast cells viability $\%$ at $1 \mathrm{~h}$, followed by $12 \mathrm{~h}$ and there was nonsignificant difference with $1 \mathrm{~h}$. The least mean of fibroblast cells viability $\%$ was at $24 \mathrm{~h}$ and there was non-significant difference with $12 \mathrm{~h}$. Dentosafe showed the highest mean of fibroblast cells viability $\%$ at $12 \mathrm{~h}$, followed by $24 \mathrm{~h}$ that showed non-significant difference with $12 \mathrm{~h}$, and the least mean was at $1 \mathrm{~h}$ (Table 2, Figure $3 \mathrm{~b}$ ).

\section{Immunofluorescence staining and H-score of cultured PDLFs (b-FGF protein expression)}

Immunofluorescence examination of PDLFs in each media at different incubation periods showed difference in the intensity of positive anti-b-FGF immune staining. PBS at $12 \mathrm{~h}$ and $24 \mathrm{~h}$ as well as Dentosafe and skimmed milk at all time intervals showed strong immune staining intensity. PBS at $1 \mathrm{~h}$ and contact lens solution at $12 \mathrm{~h}$ and $24 \mathrm{~h}$ represented moderate immune staining intensity. Contact lens solution at $1 \mathrm{~h}$ and mouthwash at all incubation periods showed weak immune staining intensity (Figure 4).

Statistical analysis of H-score of IF stained sections "based on percentage of PDLFs and staining intensity" of different media at the same incubation period represented that, at $1 \mathrm{~h}$ incubation, PBS had the highest mean of $\mathrm{H}$-score followed by Dentosafe, skimmed milk and contact lens solution respectively. Mouthwash revealed the least mean of $\mathrm{H}$-score and showed non-significant difference with contact lens solution.
At $12 \mathrm{~h}$ incubation, PBS had the highest mean of H-score followed by Dentosafe which showed non-significant difference with PBS, then skimmed milk which showed non-significant difference with Dentosafe, followed by contact lens solution. Mouthwash had the least mean of H-score.

At $24 \mathrm{~h}$ incubation, PBS showed the highest mean of $\mathrm{H}$-score followed by Dentosafe, after that skimmed milk which showed non-significant difference with Dentosafe, then contact lens solution. Mouthwash showed the least mean of H-score and showed non-significant difference with contact lens solution (Table 3, Figure 5a).

Statistical analysis of $\mathrm{H}$-score at different durations of the same medium represented that, PBS, contact lens solution, skimmed milk and Dentosafe had the highest mean of $\mathrm{H}$-score at $12 \mathrm{~h}$, followed by $24 \mathrm{~h}$, then $1 \mathrm{~h}$ and there was non-significant difference with $24 \mathrm{~h}$. Mouthwash showed the highest mean of $\mathrm{H}$-score at $12 \mathrm{~h}$, followed by $24 \mathrm{~h}$, and the least mean was at $1 \mathrm{~h}$ (Table 4 , Figure $5 \mathrm{~b}$ ).

\section{qRT-PCR of cultured PDLFs (b-FGF gene expression)}

At $1 \mathrm{~h}$ incubation, contact lens solution and mouthwash showed down-regulation of b-FGF gene expression, while skimmed milk and Dentosafe showed up-regulation of gene expression.

At $12 \mathrm{~h}$ and $24 \mathrm{~h}$ incubation, contact lens solution, skimmed milk and Dentosafe showed up-regulation of gene expression, while mouthwash showed down-regulation of gene expression (Table 5, Figure 6).

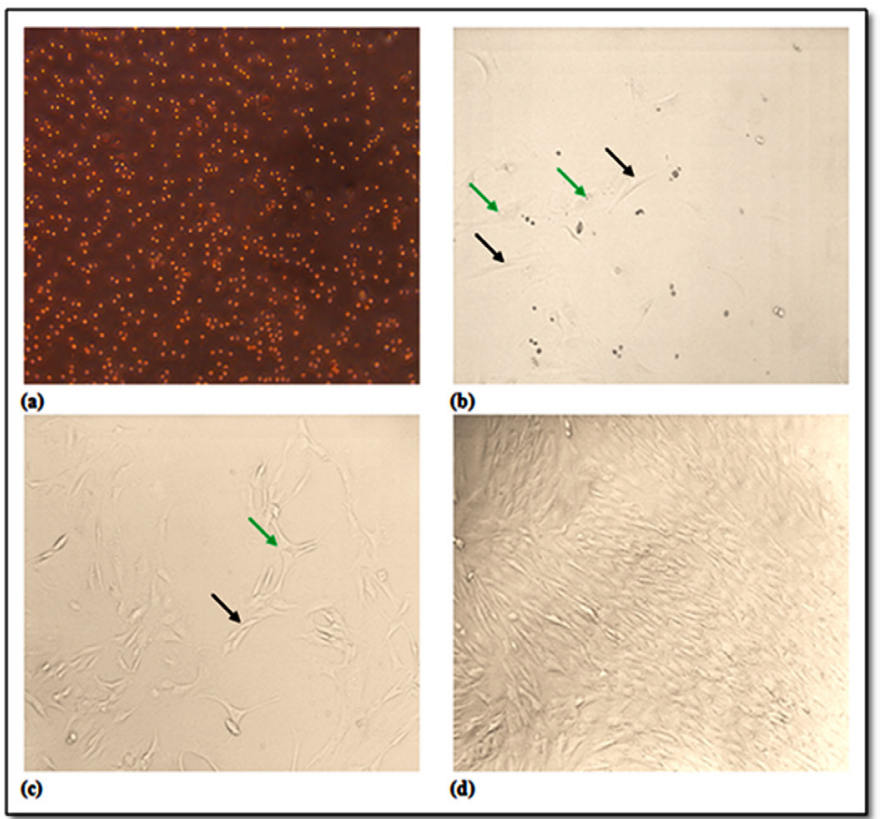

Fig. 1: photomicrographs showing primary culture of rabbit PDLSCs at different passages: (a) Day 0, showing numerous small rounded cells. (b) Passage 1, showing fibroblast-like cells (black arrows) with vesicular nucleus (green arrows). (c) Passage 2, showing cluster of fibroblast-like cells with spindle shape (black arrow) and stellate shape (green arrow). (d) Passage 3, showing numerous number of spindle shape cells (Phase contrast inverted microscope, unstained, original magnification $\mathrm{x} 200$ ) 


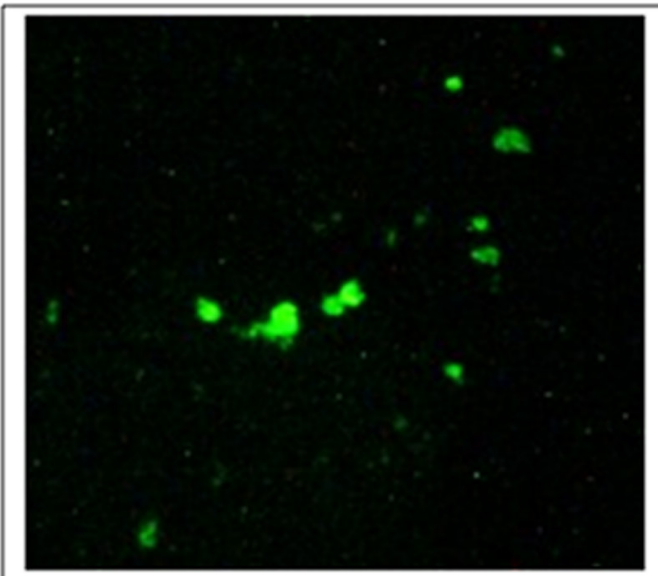

(a)

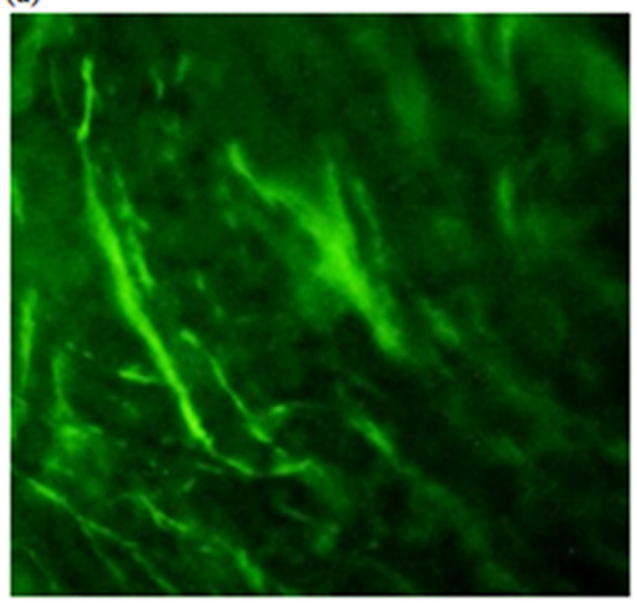

(c)

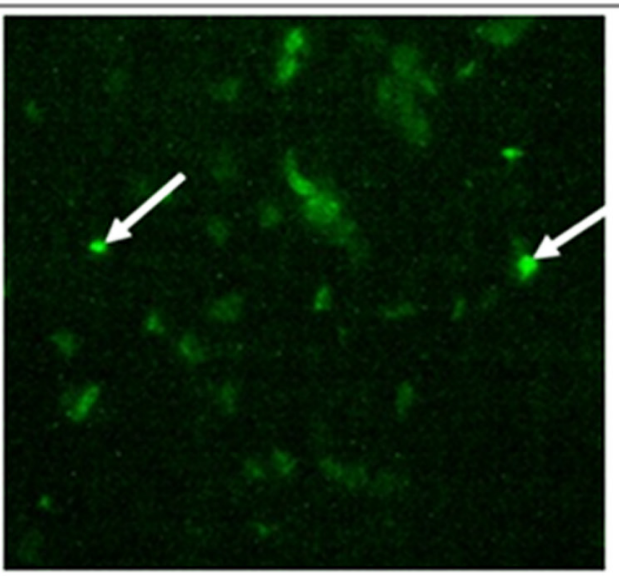

(b)

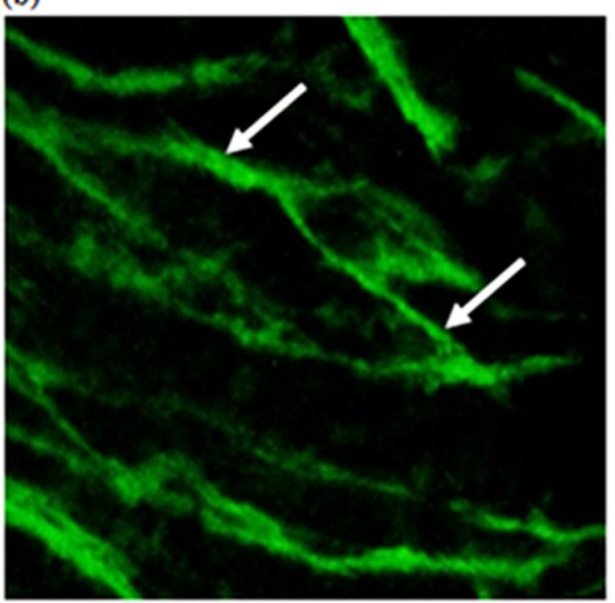

(d)

Fig. 2: Immunofluorescence photographs: PDLFs before fibroblastic differentiation showing (a) few number of PDLFs (b) with rounded shape (arrows) PDLFs after fibroblastic differentiation showing (c) detectable increase in number of PDLFs (d) with spindle shape and long processes (arrows) (Anti-b-FGF, original magnification (a\&c) x100, (b\&d) x400).

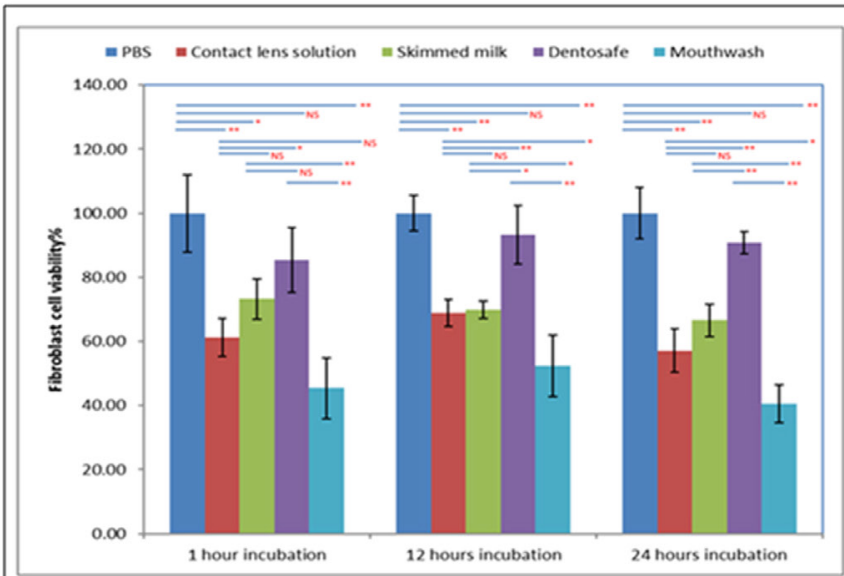

(a)

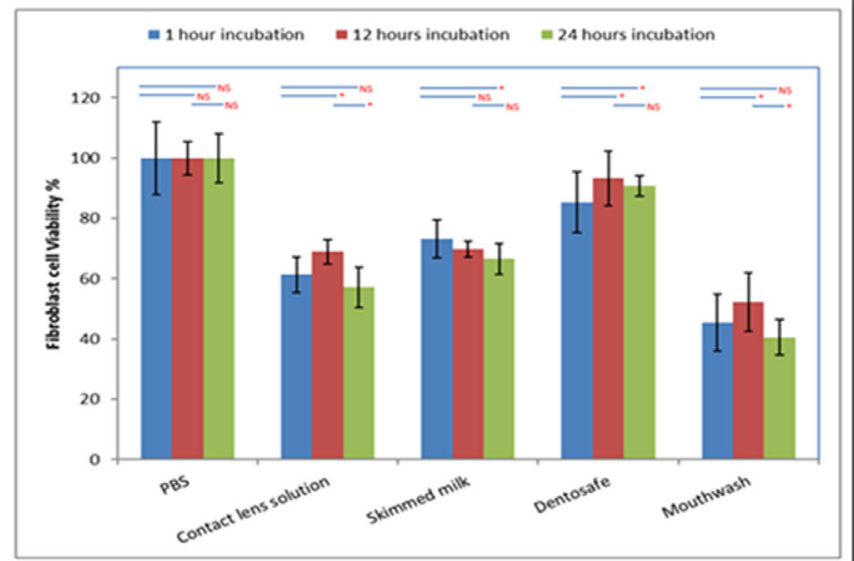

(b)

Fig. 3: Bar chart representing mean and SD values of fibroblast cells viability\% (a) Different media at same time interval. (b) Different time intervals of same medium (* Significant; ** Highly significant; NS: non-significant). 


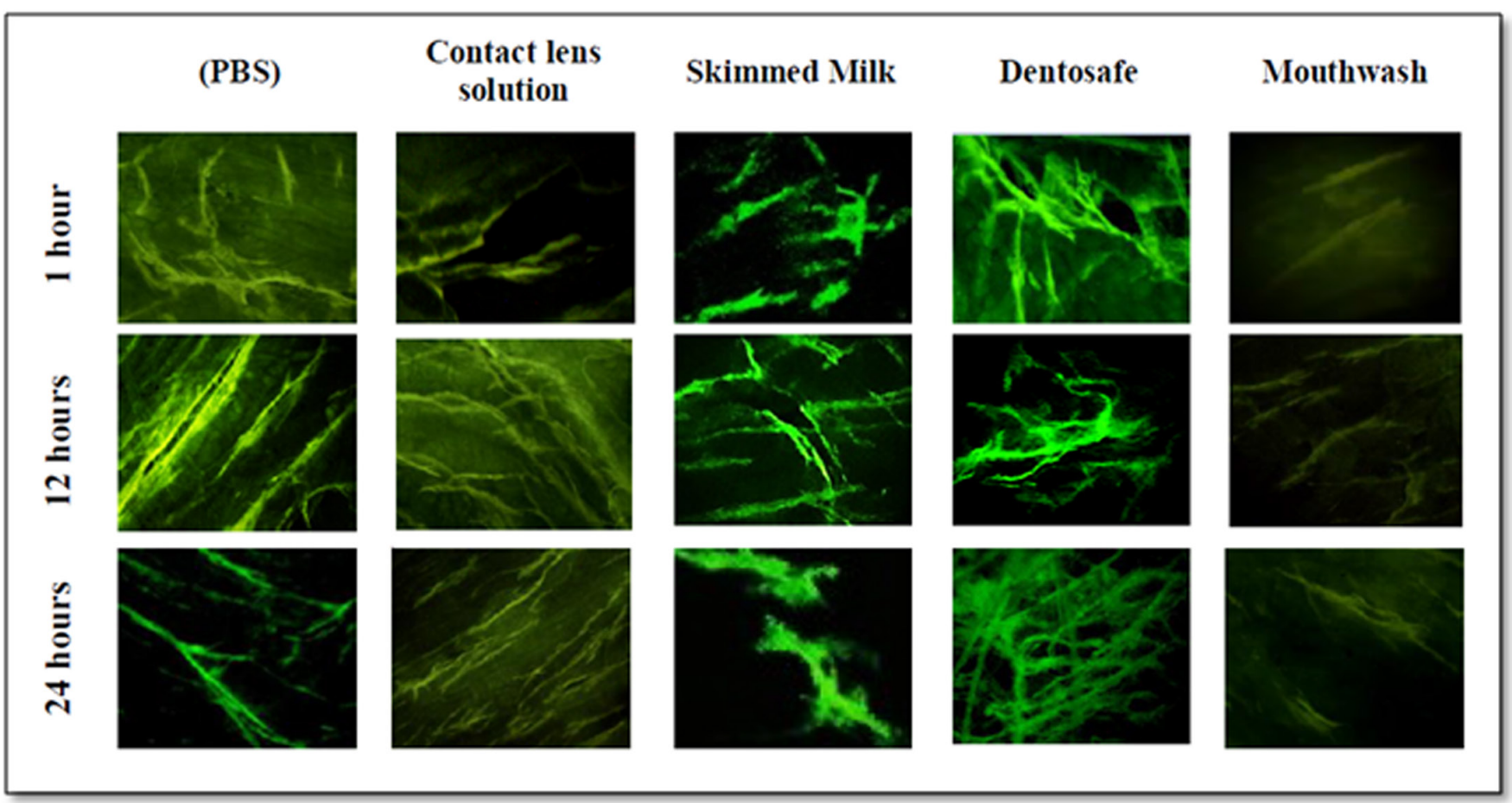

Fig. 4: Immunofluorescence photographs of cultured PDLFs in each media at three time intervals showing: PBS at 12h and 24h, Dentosafe and skimmed milk at all time intervals with strong positive immune intensity. PBS at $1 \mathrm{~h}$ and contact lens solution at $12 \mathrm{~h}$ and $24 \mathrm{~h}$ representing moderate positive immune intensity Contact lens solution at $1 \mathrm{~h}$ and mouthwash at all time intervals showing weak positive immune intensity (Anti-b-FGF, original magnification $\mathrm{x} 400$ ).

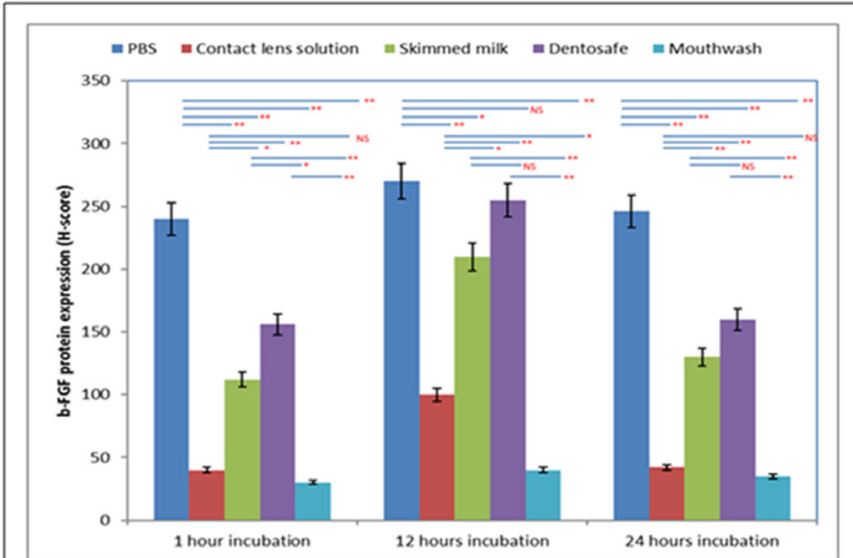

(a)

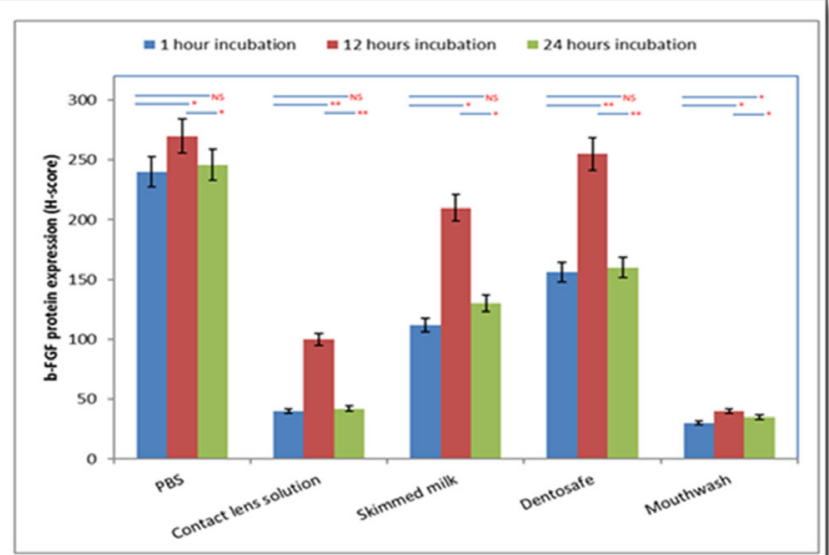

(b)

Fig. 5: Bar chart representing mean and SD values of b-FGF protein expression (H-score) (a) Different media at same time interval. (b) Different time intervals of same medium (* Significant; ** Highly significant; NS: non-significant). 


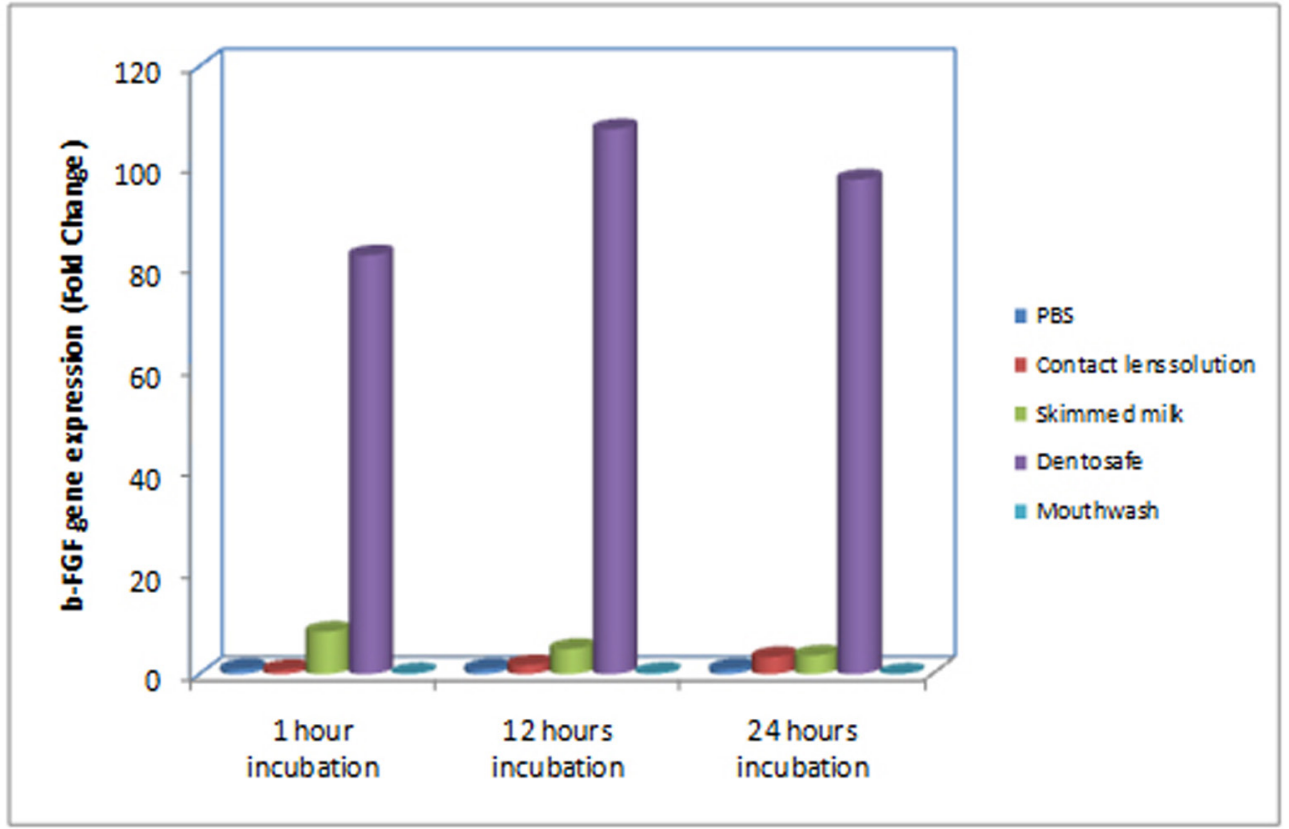

Fig. 6: Bar chart representing b-FGF gene expression (Fold change) of various media at different time intervals.

Table 1: Showing the mean \pm SD values, results of ANOVA and Least Significant Difference post hoc tests for the comparison between different media at same time interval regarding fibroblast cells viability $\%$

\begin{tabular}{|c|c|c|c|c|c|c|c|c|}
\hline \multicolumn{2}{|c|}{ Fibroblast cells viability $\%$} & PBS & Contact lens solution & Skimmed milk & Dentosafe & Mouthwash & ANOVA & $p$-value \\
\hline \multirow{2}{*}{1 hour incubation } & Mean & 99.97 & $61.30^{\mathrm{a}}$ & $73.20^{\mathrm{a}}$ & $85.40^{\mathrm{b}}$ & $45.43^{\mathrm{acd}}$ & \multirow{2}{*}{16.214} & \multirow{2}{*}{$<0.001^{* *}$} \\
\hline & $\pm \mathrm{SD}$ & 12.01 & 5.87 & 6.33 & 10.13 & 9.47 & & \\
\hline \multirow{2}{*}{12 hours incubation } & Mean & 100 & $68.90^{\mathrm{a}}$ & $69.85^{\mathrm{a}}$ & $93.33^{\mathrm{bc}}$ & $52.37^{\mathrm{abcd}}$ & \multirow{2}{*}{24.749} & \multirow{2}{*}{$<0.001^{* *}$} \\
\hline & $\pm \mathrm{SD}$ & 5.47 & 4.12 & 2.65 & 9.09 & 9.68 & & \\
\hline \multirow{2}{*}{24 hours incubation } & Mean & 99.97 & $57.17^{\mathrm{a}}$ & $66.58^{\mathrm{a}}$ & $90.83^{\mathrm{bc}}$ & $40.53^{\mathrm{abcd}}$ & \multirow{2}{*}{49.017} & \multirow{2}{*}{$<0.001^{* *}$} \\
\hline & $\pm \mathrm{SD}$ & 8.02 & 6.67 & 5.06 & 3.39 & 5.95 & & \\
\hline
\end{tabular}

Using: One Way Analysis of Variance; **p-value $<0.001 \mathrm{HS}$

post hoc, LSD: Superscript letters indicate; a: significant difference with PBS, b: significant difference with contact lens solution, c: significant difference with skimmed milk, d: significant difference with Dentosafe.

Table 2: Showing the mean \pm SD values, results of ANOVA and Least Significant Difference post hoc tests for the comparison between different time intervals of same medium regarding fibroblast cells viability\%

\begin{tabular}{|c|c|c|c|c|c|c|}
\hline \multicolumn{2}{|c|}{ Fibroblast cell Viability\% } & \multirow{3}{*}{$\begin{array}{c}1 \text { hour incubation } \\
99.97 \\
12.01\end{array}$} & \multirow{3}{*}{$\begin{array}{c}12 \text { hours incubation } \\
100 \\
5.47\end{array}$} & \multirow{3}{*}{$\begin{array}{c}24 \text { hours incubation } \\
99.97 \\
8.02\end{array}$} & \multirow{3}{*}{$\begin{array}{c}\text { ANOVA } \\
0.021\end{array}$} & \multirow{3}{*}{$\frac{p \text {-value }}{0.872}$} \\
\hline \multirow{2}{*}{ PBS } & Mean & & & & & \\
\hline & $\pm \mathrm{SD}$ & & & & & \\
\hline \multirow{2}{*}{ Contact lens solution } & Mean & 61.30 & $68.90^{\mathrm{a}}$ & $57.17^{\mathrm{b}}$ & \multirow{2}{*}{3.325} & \multirow{2}{*}{$0.032^{*}$} \\
\hline & $\pm \mathrm{SD}$ & 5.87 & 4.12 & 6.67 & & \\
\hline \multirow{2}{*}{ Skimmed milk } & Mean & 73.20 & 69.85 & $66.58^{\mathrm{a}}$ & \multirow{2}{*}{4.354} & \multirow{2}{*}{$0.027^{*}$} \\
\hline & $\pm \mathrm{SD}$ & 6.33 & 2.65 & 5.06 & & \\
\hline \multirow{2}{*}{ Dentosafe } & Mean & 85.40 & $93.33^{\mathrm{a}}$ & $90.83^{\mathrm{a}}$ & \multirow{2}{*}{3.952} & \multirow{2}{*}{$0.031^{*}$} \\
\hline & $\pm \mathrm{SD}$ & 10.13 & 9.09 & 3.39 & & \\
\hline \multirow{2}{*}{ Mouthwash } & Mean & 45.43 & $52.37^{\mathrm{a}}$ & $40.53^{b}$ & \multirow{2}{*}{7.316} & \multirow{2}{*}{$0.016^{*}$} \\
\hline & $\pm \mathrm{SD}$ & 9.47 & 9.68 & 5.95 & & \\
\hline
\end{tabular}

Using: One Way Repeated Measures Analysis of Variance. p-value $>0.05 \mathrm{NS}$; *p-value $<0.05 \mathrm{~S}$; **p-value $<0.001 \mathrm{HS}$.

Post hoc, LSD: Superscript letters indicate; a: significant difference with $1 \mathrm{~h}$.; b: significant difference with $12 \mathrm{~h}$. 
Table 3: Showing the mean \pm SD values, results of ANOVA and Least Significant Difference post hoc tests for the comparison between different media at same time interval regarding b-FGF protein expression $(\mathrm{H}$-score)

\begin{tabular}{|c|c|c|c|c|c|c|c|c|}
\hline \multicolumn{2}{|c|}{ Fibroblast cells viability $\%$} & \multirow{3}{*}{$\begin{array}{c}\text { PBS } \\
240 \\
12.7\end{array}$} & \multirow{3}{*}{$\begin{array}{c}\text { Contact lens solution } \\
40^{\mathrm{a}} \\
2.1\end{array}$} & \multirow{3}{*}{$\begin{array}{c}\text { Skimmed milk } \\
112^{\mathrm{ab}} \\
5.9\end{array}$} & \multirow{3}{*}{$\begin{array}{c}\text { Dentosafe } \\
156^{\mathrm{abc}} \\
8.3\end{array}$} & \multirow{3}{*}{$\begin{array}{c}\text { Mouthwash } \\
30^{\text {acd }} \\
1.6\end{array}$} & \multirow{3}{*}{$\begin{array}{c}\text { ANOVA } \\
262.5\end{array}$} & \multirow{3}{*}{$\begin{array}{l}\text { p-value } \\
<0.001^{* *}\end{array}$} \\
\hline \multirow{2}{*}{1 hour incubation } & Mean & & & & & & & \\
\hline & $\pm \mathrm{SD}$ & & & & & & & \\
\hline \multirow{2}{*}{12 hours incubation } & Mean & 270 & $100^{\mathrm{a}}$ & $210^{\mathrm{ab}}$ & $255^{\mathrm{b}}$ & $40^{\text {abcd }}$ & \multirow{2}{*}{255.556} & \multirow{2}{*}{$<0.001^{* *}$} \\
\hline & $\pm \mathrm{SD}$ & 14.3 & 5.3 & 11.1 & 13.5 & 2.1 & & \\
\hline \multirow{2}{*}{24 hours incubation } & Mean & 246 & $42^{\mathrm{a}}$ & $130^{\mathrm{ab}}$ & $160^{\mathrm{ab}}$ & $35^{\text {acd }}$ & \multirow{2}{*}{257.317} & \multirow{2}{*}{$<0.001^{*}$} \\
\hline & $\pm \mathrm{SD}$ & 13 & 2.2 & 6.9 & 8.5 & 1.9 & & \\
\hline
\end{tabular}

Using: One Way Analysis of Variance; **p-value $<0.001 \mathrm{HS}$

post hoc, LSD: Superscript letters indicate; a: significant difference with PBS, b: significant difference with contact lens solution, c: significant difference with skimmed milk, d: significant difference with Dentosafe.

Table 4: showing the mean \pm SD values, results of ANOVA and Least Significant Difference post hoc tests for the comparison between different time intervals of same medium regarding b-FGF protein expression (H-score)

\begin{tabular}{|c|c|c|c|c|c|c|}
\hline \multicolumn{2}{|c|}{ Fibroblast cell Viability\% } & 1 hour incubation & 12 hours incubation & 24 hours incubation & ANOVA & $p$-value \\
\hline \multirow{2}{*}{ PBS } & Mean & 240 & $270^{\mathrm{a}}$ & $246^{\mathrm{b}}$ & \multirow{2}{*}{30.250} & \multirow{2}{*}{$<0.001^{* *}$} \\
\hline & $\pm \mathrm{SD}$ & 12.7 & 14.3 & 13 & & \\
\hline \multirow{2}{*}{ Contact lens solution } & Mean & 40 & $100^{\mathrm{a}}$ & $42^{\mathrm{b}}$ & \multirow{2}{*}{52.680} & \multirow{2}{*}{$<0.001^{* *}$} \\
\hline & $\pm \mathrm{SD}$ & 2.1 & 5.3 & 2.2 & & \\
\hline \multirow{2}{*}{ Skimmed milk } & Mean & 112 & $210^{\mathrm{a}}$ & $130^{\mathrm{b}}$ & \multirow{2}{*}{30.730} & \multirow{2}{*}{$<0.001^{* *}$} \\
\hline & $\pm \mathrm{SD}$ & 5.9 & 11.1 & 6.9 & & \\
\hline \multirow{2}{*}{ Dentosafe } & Mean & 156 & $255^{\mathrm{a}}$ & $160^{\mathrm{b}}$ & \multirow{2}{*}{22.288} & \multirow{2}{*}{$<0.001^{* *}$} \\
\hline & $\pm \mathrm{SD}$ & 8.3 & 13.5 & 8.5 & & \\
\hline \multirow{2}{*}{ Mouthwash } & Mean & 30 & $40^{\mathrm{a}}$ & $35^{\mathrm{ab}}$ & \multirow{2}{*}{11.707} & \multirow{2}{*}{$<0.001^{* *}$} \\
\hline & $\pm \mathrm{SD}$ & 1.6 & 2.1 & 1.9 & & \\
\hline
\end{tabular}

Using: One Way Repeated Measures Analysis of Variance. **p-value $<0.001 \mathrm{HS}$.

Post hoc, LSD: Superscript letters indicate; a: significant difference with 1h.; b: significant difference with $12 \mathrm{~h}$.

Table 5: Showing b-FGF gene expression (Fold change) of various media at different time intervals.

\begin{tabular}{ccccc}
\hline $\begin{array}{c}\text { b-FGF gene expression } \\
\text { (Fold change) }\end{array}$ & PBS & Contact lens solution & Skimmed milk & Dentosafe \\
\hline 1 hour incubation & 1 & 0.84 & 8.39 & 82.71 \\
12 hours incubation & 1 & 1.79 & 4.99 & 0.21 \\
24 hours incubation & 1 & 3.38 & 3.70 & 0.28 \\
\hline
\end{tabular}

\section{DISCUSSION}

Tooth avulsion is a severe dental trauma and most frequently occurred in children between 8-12 years old. Using of storage media before avulsed tooth replantation to maintain PDLFs viability (responsible of the extracellular matrix production and PDL regeneration) is an essential prognostic factor ${ }^{[21,22]}$.

Albino rabbit was the animal of choice in this study because it is easily available, it is simple to handle and it has large root surface area that provide more sample size of PDL tissues ${ }^{[23]}$.

In the present study, skimmed milk was used instead of whole milk because of its high cell viability ${ }^{[24]}$.

In this study, non-alcoholic mouthwash was used as recommended by De Paola and Spolarich ${ }^{[25]}$, since mouthwash containing alcohol causes oral cancer ${ }^{[26]}$.
The metabolic activity of incubated cells was measured by colorimetric MTT assay in this study; since it is a widely used method to test the viability of different cell types such as fibroblast ${ }^{[27]}$.

In herein study, b-FGF protein and gene expressions were assessed because b-FGF is formed mainly by fibroblast and it has main functions in PDL regeneration through its angiogenesis and chemotaxis properties, its proliferative capacity of undifferentiated cells in PDL and its ability to enhance bone formation as well as prevention of ankylosis and root resorption ${ }^{[28,29]}$.

In the current study, cultured PDLSCs exhibited adherence to culture plastic flask floor and showed fibroblasts-like morphology. These findings are in accordance with Bağ and Yildirim ${ }^{[30]}$. 
In the present study, the differentiated DPLFs showed positive IF staining reaction to anti-b-FGF. Fibroblasts revealed detectable increase in number and appearance of their characteristic spindle shape. This result is in agreement with Grzibovskis et al., ${ }^{[31]}$.

In this study PBS was used as a control medium and statistically showed the highest mean value of viable PDLFs. This could be referred to its ideal osmolarity and $\mathrm{pH}$ as well as its biocompatibility that help in maintaining physical integrity of cells ${ }^{[32,33]}$.

In the current study, the statistical analysis of MTT assay result suggested that, Dentosafe is more effective in the maintenance of cells viability in comparison to contact lens solution, skimmed milk and mouthwash when PDLFs stored for longer time intervals. The effectiveness of Dentosafe could be related to special culture media which represent one of its ingredients ${ }^{[12]}$. This result is coinciding with Lee et al.,${ }^{[34]}$ who recorded the superiority of Dentosafe as preservative medium for human PDLFs in comparison to other media after 12 and 24 hours of incubation. Moreover, Dentosafe demonstrated $75 \%$ healing rate when used as a storage media before replantation of avulsed teeth ${ }^{[35,36]}$. Despite of its value in maintaining vitality of PDL cells, the negative aspect of this medium is the difficulty to be found in many countries ${ }^{[37,38]}$.

In the present study, statistical analysis of MTT assay result showed the ability of skimmed milk in maintaining PDLFs viability at all time intervals in comparison to contact lens solution and mouthwash. This finding could be related to neutral $\mathrm{pH}$ and physiological osmolarity of the milk, in addition to its growth factors which are crucial to cells ${ }^{[39]}$. Moreover, Adnan et al. ${ }^{[40]}$ reported that, the lower fat content milk is considered an excellent alternative storage media for avulsed teeth.

In the current study, skimmed milk showed significant less mean value of viable cells at 12 and $24 \mathrm{~h}$ incubation in comparison to Dentosafe and at all time intervals in comparison to PBS. Our findings were not in line with Martins et al., ${ }^{[39]}$ who reported higher PDL cells viability of milk than PBS when the cells incubated at room temperature at $10 \mathrm{~h}$ and $24 \mathrm{~h}$. This conflict could be attributed to higher incubation temperature used in herein study that may alternate skimmed milk efficiency through decreasing its freshness and increasing fragmentation of its contents to some extent ${ }^{[41,42]}$. However, milk is highly recommended in other studies because it is inexpensive, rich of nutrients and easily to be found than other media as well as it protects PDLF viability and identity ${ }^{[30,40]}$.

In the present study, the mean of PDLFs cells viability $\%$ in contact lens solution was less than skimmed milk, although there were no statistical differences at different time intervals. This finding is in agreement with Sigalas et al. ${ }^{[43]}$; Chamorro et al., ${ }^{[44]}$. This could be related to the harmful effect of preservatives in contact lens solution on PDL cells especially with long storage time. Moreover, in the current study, the mean of viable cells that incubated in contact lens solution was decreased at $24 \mathrm{~h}$ incubation. This finding is in parallel with Anegundi and Daruwalla ${ }^{[45]}$ who recommended that the contact lens solution is better to be used for short storage time.

Statistically, mouthwash showed the least mean value of PDLFs viability\% at all time intervals in this study. This result is in parallel with de Oliveira et al. ${ }^{[46]}$ who reported cytotoxic effect of different types of mouthwash on gingival fibroblasts. This finding could be attributed to antiseptic properties of mouthwash linked to its biocompound formulations of plant and vegetal origin; these compounds penetrate cell membrane causing cell death and ATP depletion due to inhibition of both mitochondria metabolic activity and cell proliferation ${ }^{[47-50]}$.

In the current study, cultured PDLFs showed positive anti-b-FGF IF stain reaction in different media after each incubation period. This is related to the ability of b-FGF in maintaining self renewal and differentiation potency in vitro $^{[51]}$.

In the present study, statistical analysis of examined IF stained sections according to percentage of PDLFs and staining intensity (H-score) of different media at three time intervals represented that, PBS showed the highest mean value followed by Dentosafe, skimmed milk, contact lens solution, and mouthwash respectively. The statistical results of $\mathrm{H}$-score were coinciding with the fibroblast cells viability $\%$ result in this study. This is in agreement with Kim et al., ${ }^{[52]}$ who reported that, the histological examination of the PDL cells in vitro study was equivalent to MTT assay result.

In this study, results of b-FGF relative gene expression (fold change) demonstrated that, Dentosafe and skimmed milk showed up-regulation of b-FGF gene expression at all time intervals and contact lens solution at $12 \mathrm{~h}$ and $24 \mathrm{~h}$ incubation. These results coincide with PDLFs IF staining intensity in this study and are in accordance with Pohl et al., ${ }^{[35]}$; Sinpreechanon et al., ${ }^{[53]}$ who reported functional activity of PDLFs after incubation in Dentosafe and low-fat milk respectively. Conversely, mouthwash showed downregulation of b-FGF gene at all incubation periods, this was confirmed by the weak IF staining intensity of PDLFs as reported in this study and its cytotoxic effect that inhibits protein and DNA synthesis in fibroblast as reported by de Oliveira et al., ${ }^{[46]}$; Coelho et al., ${ }^{[54]}$.

\section{CONCLUSIONS}

This study suggested that, for all storage times (1, 12 and $24 \mathrm{~h}$ ), Dentosafe is more effective in the maintenance of PDLFs viability and function than other tested media. Contact lens solution and skimmed milk showed almost the same cell viability but regarding function, skimmed milk is more preferred. In addition, it is better to use contact lens solution and skimmed milk as storage media not more than $12 \mathrm{~h}$. Mouthwash is not recommended to be used as a storage media for PDLFs. 


\section{CONFLICT OF INTERESTS}

There are no conflicts of interest.

\section{REFERENCES}

1. Soares AJ, Gomes BP, Zaia AA, Ferraz CC and de Souza-Filho FJ: Relationship between clinicalradiographic evaluation and outcome of teeth replantation. Dent Traumatol. (2008) 24:183-188.

2. Andreasen JO, Andreasen FM and Andersson L: Textbook and Color Atlas of Traumatic Injuries to the Teeth $\left(5^{\text {th }}\right.$ ed.). Oxford, Wiley-Blackwell. (2018) pp.327-354.

3. Krasner P: Treatment of avulsed teeth by oral and maxillofacial surgeons. J Oral Maxillofac Surg. (2010) 68:2888-2892.

4. Goswami M, Chaitra T, Chaudhary S, Manuja N and Sinha A: Strategies for periodontal ligament cell viability: an overview. J Conserv Dent. (2011) 14:215-220.

5. Murakami S: Peridontal tissue regeneration by signaling molecule(s): what role does basic fibroblast growth factor (FGF 2) have in peridontal therapy? Peridontol 2000. (2011) 56:188 208.

6. Rodríguez-Lozano FJ, Insausti CL, Iniesta F, Blanquer M, Ramírez MC, Meseguer L, Meseguer-Henarejos A, Marín N, Martínez S and Moraleda J: Mesenchymal dental stem cells in regenerative dentistry. Medicina Oral Patología Oraly Cirugia Bucal. (2012) 17:1062-1067.

7. Bai Y, Li P, Yin G, Huang Z, Liao X, Chen X and Yao Y: BMP 2, VEGF and bFGF synergis $\neg$ tically promote the osteogenic differentiation of rat bone marrow derived mesenchymal stem cells. Biotechnol Lett. (2013) 35:301308.

8. Tuna EB, Yaman D and Yamamato S: What is the Best Root Surface Treatment for Avulsed Teeth? Open Dent J. (2014) 8:175-179.

9. Khinda VI, Kaur G, Brar GS, Kallar S and Khurana $\mathrm{H}$ : Clinical and practical implications of storage media used for tooth avulsion. Int J Clin Pediatr Dent. (2017) 10:158-165.

10. Weine FS: Endodontic Therapy. 6th edition. St Louis: C.V. Mosby Company. )2004( p367-373.

11. Bazmi BA, Singh AK, Kar S and Mubtasum $\mathrm{H}$ : Storage media for avulsed tooth $-\mathrm{a}$ review. Ind J Multidis Dent. (2013) 3(3):741-749.

12. Sanghavi T, Shah N, Parekh V and Singbal $\mathrm{K}$ : Evaluation and comparison of efficacy of three different storage media, coconut water, propolis and oral rehydration solution, in maintaining the viability of periodontal ligament cells. J Conserv Dent. (2013)16:71-74
13. Anyanwu OC, Baugh KK, Bennett SB, Johnson JM, Madlock RL, Pollard NE, et al: Comparison of the Antibacterial Effectiveness of Alcohol containing and Non-alcohol-containing Mouthwashes. J Sci. (2011) 2:7-12.

14. Flemingson, Emmadi $\mathrm{P}$, Ambalavanan $\mathrm{N}$, Ramakrishnan T and Vijayalakshmi R: Effect of three commercial mouth rinses on cultured human gingival fibroblast: An in vitro study: Indian J Dent Res. (2008)19(1):29-35.

15. Zhu W, Zhang Q, Zhang Y, Cen L and Wang J: (PDL regeneration via cell homingin delayed replantation of avulsed teeth. J Transl Med. (2015) 13:357.

16. De souza B, Alves A, Sanos L, Felippe W and Felippe M: Fibroblast Viability after Storage At $20^{\circ} \mathrm{C}$ in Milk, Hank"s Balanced Salt Solution and Coconut Water. Braz. Dent. J. (2016) 27(4): 404-407.

17. Nawrocka D, Kornicka K, Szydlarska J and Marycz K: Basic Fibroblast Growth Factor Inhibits Apoptosis and Promotes Proliferation of Adipose-Derived Mesenchymal Stromal Cells Isolated from Patients with Type 2 Diabetes by Reducing Cellular Oxidative Stress. Oxid. Med. Cell. Longev. (2017) 2017:1-22.

18. Yoon D, Yoon D, Sim H, Hwang I, Lee J and Chun W: Accelerated Wound Healing by Fibroblasts Differentiated from Human Embryonic Stem CellDerived Mesenchymal Stem Cells in a Pressure Ulcer Animal Model. Stem Cells Int. (2018) 2018:1-12.

19. Kalcheim C and Neufeld G: Expression of basic fibroblast growth factor in the nervous system of early avian embryos. Development. (1990)109, 203-215.

20. Xie J, Ma Y, Wan M, Zhan R and Zhou Y: Expression of dedifferentiation markers and multilineage markers in U251 glioblastoma cells with silenced EGFR and FGFR genes. Oncol. Lett. (2014) 7: 131-136.

21. Ram D and Cohenca N: Therapeutic Protocols for Avulsed Permanent Teeth: Review and Clinical Update. Pediatr Dent. (2004) 26: 251-255.

22. Savas S, Kucukyilmaz E, Akcay M and Koseoglu S: Delayed replantation of avulsed teeth: Two case reports. Case Reports in Dentistry. (2015) 2015, 1-5.

23. Mapara M, Thomas BS and Bhat KM: Rabbit as an animal model for experimental research. Dent Res J. (2012) 9(1):111-118.

24. Moura CC, Soares PB, de Paula Reis MV, FernandesNeto AJ, Zanetta Barbosa D and Soares $\mathrm{CJ}$ : Potential of coconut water and soy milk for use as storage media to preserve the viability of periodontal ligament cells: An in-vitro study. Dent Traumatol. (2014) 30:22-26. 
25. De Paola LG and Spolarich AE: Safety and Efficacy of Antimicrobial Mouthrinses in Clinical Practice. J Dent Hyg. (2007) 81(1):117.

26. De Blanc SA and Baruzzi AM: Mouthrinses Containing Alcohol and Oral Cancer. Revision of Epidemiological Studies. Braz Oral Res. (2007) 21(spe):16-22.

27. Scelza MZ, Coil J and Alves GG: Effect of time of extraction on the biocompatibility of endodontic sealers with primary human fibroblasts. Braz Oral Res. (2012) 26(5): 424-430.

28. Seshima F, Ota M, Kinumatsu T, Shibukawa Y and Yamada S: Effect of recombinant basic fibroblast growth factor on reimplanted teeth in beagle dogs. Oral Surg Oral Med Oral Pathol Oral Radiol Endod. (2010) 109:142-148.

29. Yu S, Lee J, Jung U, Park J, Kim B and Choi S: Effect of fibroblast growth factor on injured periodontal ligament and cementum after tooth replantation in dogs. J Periodontal Implant Sci. (2015) 45:111-119.

30. Bağ I and Yildirim S: Effect of avulsion storage media on periodontal ligament fibroblast differentiation. Dent Traumatol. (2017) 33(6):458-464.

31. Grzibovskis M, Urtane I and Pilmane M: Specific signaling molecule expression in periodontal ligaments in different age groups: Pilot study. Stomatologiia. (2011) 13: 117122 .

32. Marino T, West LA, Liewehr FR, Mailhot JM, Buxton TB, Runner RR and McPherson JC: Determination of periodontal ligament cell viability in long shelf-life milk. J Endod. (2000) 26:699-702.

33. Martin MP and Pileggi RA: A quantitative analysis of Propolis: a promising new storage media following avulsion. Dent Traumatol. (2004) 20:85-89.

34. Lee W, Stover S, Rasoulianboroujeni M, Sherman K, Fahimipour F, Dashtimoghadam E, Zito C, Jazayeri HE and Tayebi L: The efficacy of commercial tooth storage media for maintaining the viability of human periodontal ligament fibroblasts. Int. Endod. J. (2018) 51:58-68.

35. Pohl Y, Filippi A and Kirschner H: Results after replantation of avulsed permanent teeth. II. Periodontal healing and the role of physiologic storage and antiresorptiveregenerative therapy. Dent Traumatol. (2005) 21:93-101.

36. Werder $\mathrm{P}$, von Arx $\mathrm{T}$ and Chappuis V: Treatment outcome of 42 replanted permanent incisors with a median follow-up of 2.8 years. Schweizer Monatsschrift fur Zahnmedizin. (2011) 121:312-320.

37. Adnan $\mathrm{S}$ and khan FR: Storage Media for Avulsed teeth: A Review, JPak Dent Assoc. (2014) 23(2):54-60.
38. Khinda V, Kaur G and khurana H: Clinical and practical impllications of storage media used for avulsion. Int. J. Clin. Pediatr. Dent. (2017)10(2):158-165.

39. Martins CM, Hamanaka EF, Hoshida TY, Sell AM, Hidalgo MM, Silveira CS and Poi WR: Dragon's blood sap (croton lechleri) as storage medium for avulsed teeth: in vitro study of cell viability. Braz. Dent. J. (2016) 27(6):751-756.

40. Adnan S, Lone MM, Khan FR, Hussain SM and Nagi SE: Which is the most recommended medium for the storage and transport of avulsed teeth? A systematic review. Dent Traumatol. (2018) 34:59-70.

41. Schwartz O, Andreasen FM and Andreasen JO: Effects of temperature, storage time and media on periodontal and pulpal healing after replantation of incisors in monkeys. Dent Traumatol. (2002) 18(4): 190-195.

42. Gomes M, Westphalen V, Westphalen F, Neto U, Fariniuk L and Carneiro E: Study of storage media for avulsed teeth. Brazilian Journal of Dental Traumatology. (2009) 1(2):69-76.

43. Sigalas E, Regan JD, Kramer PR, Witherspoon DE and Opperman LA: Survival of human periodontal ligament cells in media proposed for transport of avulsed teeth. Dent Traumatol. (2004) 20:21-28.

44. Chamorro MM, Regan JD, Opperman LA and Kramer PR: Effect of storage media on human periodontal ligament cell apoptosis. Dent Traumatol. (2008) 24:11-16.

45. Anegundi RT and Daruwalla SF: Assessment of viability of periodontal ligament cells in different storage media. IJOHMR (2016) 3(1):21-27.

46. de Oliveira JR, Belato KK, de Oliveira FE, Jorge AOC, Camargo SEA and de Oliveira LD: Mouthwashes: an in vitro study of their action on microbial biofilms and cytotoxicity to gingival fibroblasts. General dentistry. (2018) 66(2):28-34.

47. Chang YC, Huang FM, Tai KW and Chou MY: The effect of sodium hypochlorite and chlorhexidine on cultured human periodontal ligament cells. Oral Surg Oral Med Oral Pathol Oral Radiol Endod. (2001) 92: 446-450.

48. Braga PC, Culici M, Alfieri M and Dal Sasso M: Thymol inhibits Candida albicans biofilm formation and mature biofilm. Int $\mathrm{J}$ Antimicrob Agents. (2008) 31(5):472-477.

49. Aria G, Cardoso CR, Larson RE, Silva JS and Rossi MA: Mechanism underlying chlorhexidine induced cytotoxicity. Toxicol Appl Pharmacol. (2009) 23: 256-265. 
50. Tsourounakis L, Palaiologou-Gallis AA, Stoute D, Maney $\mathrm{P}$ and Lallier TE: Effect of essential oil and chlorhexidine mouthwashes on gingival fibroblast survival and migration. J Periodontol. (2013) 84(8):1211-1220.

51. Levenstein ME, Ludwig TE, Xu RH, Llanas RA and VanDenHeuvel Kramer K: Manning D and Thomson JA: Basic fibroblast growth factor support of human embryonic stem cell self renewal. Stem Cells. (2006) 24: 568574

52. Kim HK, Kim ES, Choi IB, Kim J and Lee SJ: The verification of the MTT assay on the viability of periodontal ligamental cells in rat molars through the histologic examination. Restor Dent Endod. (2003) 28:385-391.

53. Sinpreechanon P, Boonzong $U$ and Sricholpech M: Comparative evaluation of periodontal ligament fibroblasts stored in different types of milk: effects on viability and biosynthesis of collagen. Eur J Oral Sci. (2019) 127: 323-332.

54. Coelho A, Laranjo M, Gonçalves A, Paula A, Paulom S, Abrantes A, Caramelo F, Ferreira M, Silva M, Carrilho E and Botelho M: Cytotoxic effects of a chlorhexidine mouthwash and of an enzymatic mouthwash on human gingival fibroblasts. Odontology. (2020) 108:260-270. 


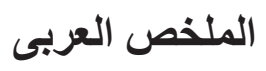

\title{
التقييم المقارن لحيوية ووظيفة الخلايا الليفية بالأربطة الداعمة للاسنان فى الارنب

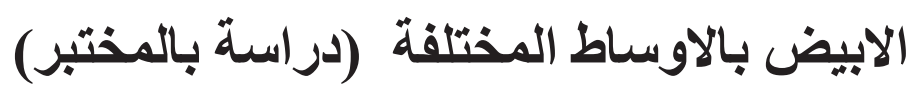

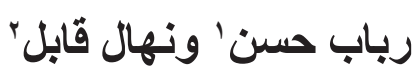

'قسم بيولوجيا الفم ـ كلية طب الأسنان - جامعة عين شمس_القاهرة-مصر.

ثقمم طب اسنان الاطفال وطب اسنان المجتمع- كلية طب الاسنان -

جامعة مصر للعلوم والتكنولوجيا - القاهرةـ مصر.

المقدمة: قلع الأسنان يعد من احدى الإصابات التي تتسبب في تلف الانسجة الداعمة للاسنان. يجب حفظ السن المخلوع في وسط مناسب للحفاظ على حيوية الخلايا الليفية. الهدف: تقييم و مقارنة تأثير الاوساط المختلفة على حيوية الخلايا الليفية ، وتعبير ات البروتين و الجين لعامل نمو الخلايا

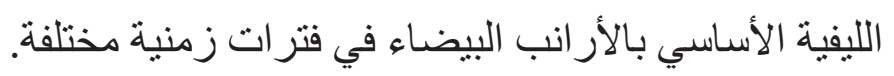

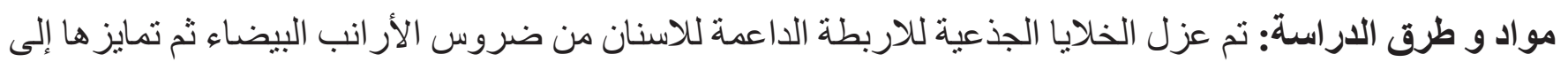

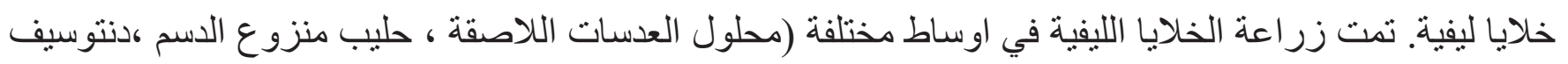

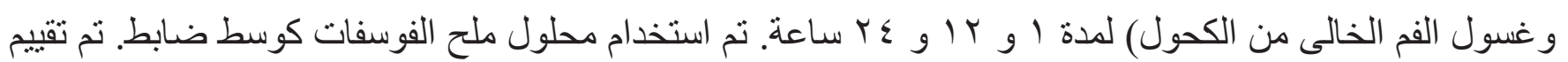
حيويه الخلية بواسطة اختبار ال ام تى تى وتم حساب مستويات البروتين والتعبير الجيني لعامل نمو الخلايا الليفية

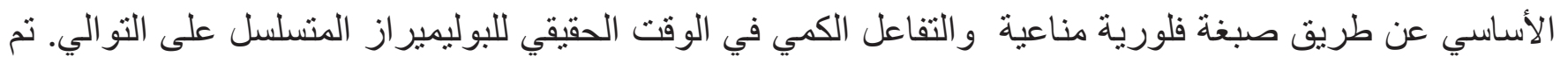
تحليل البيانات من اختبار ام تى تى ودرجة الصبغة الفلورية المناعية إحصائيًا. النتائج: أظهرت الخلايا الجذعية المعزولة من الاربطة الداعمة للاسنان أشكالا مختلفة من دائري إلى مغزلى لى. أظهرت

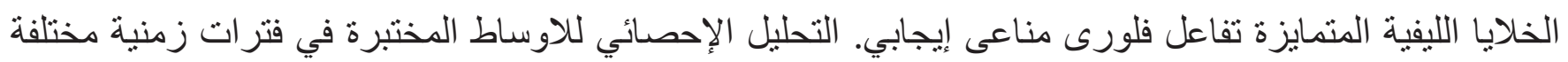

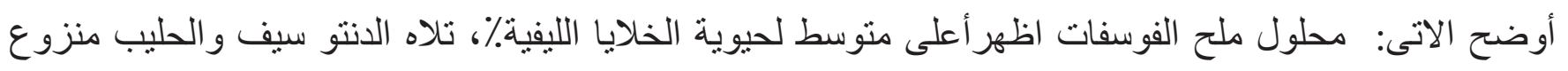

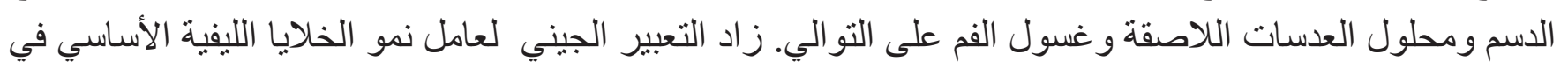

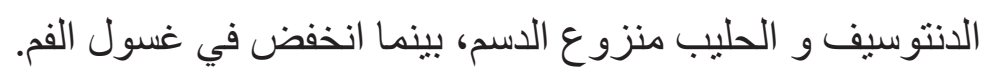

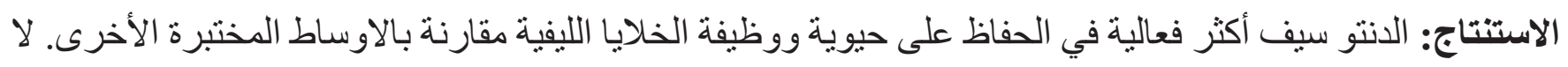
يُنصح باستخدام غسول الفم كوسط لحفظ الخلايا الليفية. 